\title{
Method of Comparative Analysis of the Structure of Food
}

\author{
Mansur Radjabov ${ }^{1 *}$ and Odil Safarov ${ }^{2}$
}

${ }^{1}$ Urgench State University, Faculty of Chemical Technology, Department of Chemical Technology, Gurlen Street, 2A, 220100, Urgench, Khorezm, Uzbekistan ${ }^{2}$ Bukhara State Institute of High Technology, Murtazaev Street, 15, 200100, Bukhara, Uzbekistan

\begin{abstract}
Pore size distribution has a large impact to determine the rational mode of drying the combined method of investigation of hygroscopic properties and the binding energy of moisture. Hence introduction of modern methods of treatment and nontraditional methods of drying fruits to produce new products that require research and mathematical description of the hygroscopic properties. The method of comparative analyses applied in this study gives the opportunity to determine diameters of pores activity of water and other parameters in dried products.
\end{abstract}

Keywords: Uzbekistan; Agriculture; Melon; Activity of water

\section{Introduction}

Food products are so complex a system as in nature, and structure that they have different types of communications moisture [1-6]. At various stages of dehydration products plays a major role or that kind of moisture.

Much of the fruit and vegetable crops subjected to drying are wet colloidal capillary- porous systems. Pore size distribution has a large impact to determine the rational mode of drying the combined method of investigation of hygroscopic properties and the binding energy of moisture [6]. Nature of the sorption and desorption isotherms depends on the type of moisture due to the material. In the hygroscopic region of connection of moisture depends on the relationship of structure and properties of materials.

\section{Results and Discussion}

There were discussed hygroscopic properties of different types of products by a number of scientists. Currently, however, introduction of modern methods of treatment and non-traditional methods of drying fruits to produce new products that require research and mathematical description of the hygroscopic properties.

In order to determine the equilibrium moisture content of fruit crops: melon varieties: - "Shakar-Palak", "Ala-puchak"-experimental studies designed and manufactured in a climate chamber. The results of these studies, the desorption isotherm melon fruits at different temperatures $\left(t=25-50^{\circ} \mathrm{C}\right)$ and relative humidity $(20-80 \%)$, are presented in Table 1 and Figure 1.

In connection with the penetration of syrup solution in the capillaries of melon flesh, determination and dissolution of the effective pore diameter of great importance. The specific surface of the remote water film is formed in the early part of the capillary condensation is determined by the method of: 4

$$
S=\frac{1}{G_{u}} \int_{U n}^{U s} \Delta r . d u
$$

G- The surface tension of liquid, $\mathrm{H} / \mathrm{M}$;

$\mathrm{U}$ - Amount of moisture in the material at saturation $\mathrm{p} / \mathrm{p}_{\mathrm{c}}=1$;

$\mathrm{U}$ - Amount of moisture in the beginning of the section of capillary condensation
L- The binding energy or differential operation dehydration product, кДж/кг.вл.

$$
L=-R T \ln \phi
$$

R- Universal gas constant, Дж/КМоль\%

According to the formula defined by the effective diameter of pores

$$
d=\frac{4 G V_{m}}{R T \ln \left(\frac{P_{n}}{P_{h}}\right)}
$$

G- the surface tension of melon juice which depends on sugar, $\mathrm{MH} / \mathrm{M}$

$\mathrm{V}$ - molar volume of water contained in the product, $\mathrm{m}^{3} /$ моль;

In order to determine the pore size by comparing different varieties of melons. Choose a melon pulp, and other varieties of the same surface wetting handle under the same conditions in the same concentration of sugar syrup. After processing in sugar syrup is binning of products within 5-10 minutes.

Calculations of the parameters listed in Table 2.

\begin{tabular}{|c|c|c|c|c|c|c|c|c|}
\hline \multirow{2}{*}{ Melon } & \multirow{8}{*}{} & \multicolumn{7}{|c|}{ Relative humidity air,\% } \\
\cline { 3 - 9 } & $\mathbf{t}^{\circ} \mathbf{C}$ & $\mathbf{2 0}$ & $\mathbf{3 0}$ & $\mathbf{4 0}$ & $\mathbf{5 0}$ & $\mathbf{6 0}$ & $\mathbf{7 0}$ & $\mathbf{8 0}$ \\
\hline Without Treatment & 25 & 10,1 & 12 & 15,8 & 18,1 & 22,6 & 26,7 & 35 \\
\hline $\begin{array}{c}\text { With Treatment } \\
\text { in sugar syrup }\end{array}$ & 25 & 11,8 & 12,5 & 18,1 & 22,4 & 25 & 32,1 & 38,8 \\
\hline Without Treatment & 50 & 4,8 & 5 & 6,1 & 8,1 & 12 & 17 & 25 \\
\hline $\begin{array}{c}\text { With Treatment } \\
\text { in Sugar Syrup }\end{array}$ & 50 & 5,1 & 6,8 & 8 & 12,1 & 15,6 & 22 & 28,5 \\
\hline
\end{tabular}

Table 1: Desorption isotherm melon processed in sugar syrup.

*Corresponding author: Mansur Radjabov, Urgench State University, Faculty of Chemical Technology, Department of Chemical Technology, Gurlen street, 2A, 220100, Urgench, Khorezm, Uzbekistan, Tel: 2266166; E mail: r-misha38@rambler.ru

Received December 24, 2013; Accepted March 18, 2014; Published March 23 2014

Citation: Radjabov M, Safarov O (2014) Method of Comparative Analysis of the Structure of Food. J Food Process Technol 5: 307. doi:10.4172/2157-7110.1000307

Copyright: ( 2014 Radjabov M, et al. This is an open-access article distributed under the terms of the Creative Commons Attribution License, which permits unrestricted use, distribution, and reproduction in any medium, provided the original author and source are credited. 


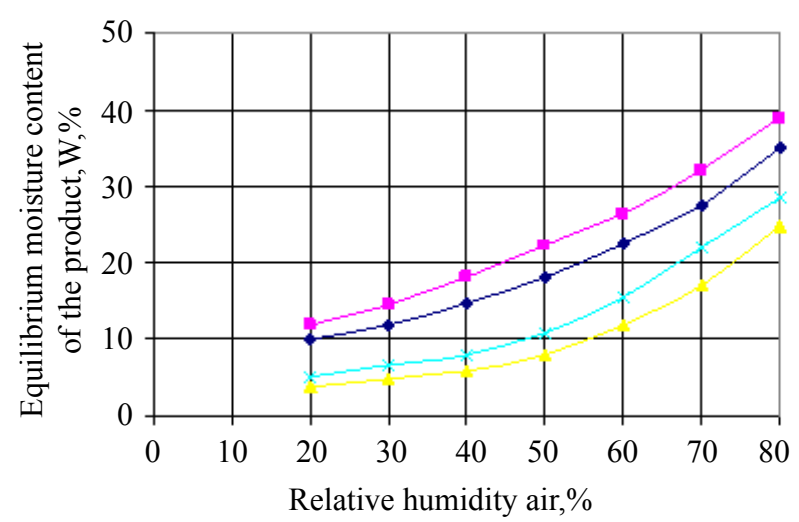

A) pre-soaked in sugar syrup: $\mathbf{m}-\mathrm{t}=25^{\circ} \mathrm{C} ; \mathrm{x}-\mathrm{t}=50^{\circ} \mathrm{C}$.

B) Without treatment: $\bullet-\mathrm{t}=25^{\circ} \mathrm{C} ; \Delta-\mathrm{t}=50^{\circ} \mathrm{C}$.

Figure 1: Desorption isotherm melon fruit depending a method of treatment.

\begin{tabular}{|c|c|c|c|c|c|c|c|c|}
\hline Humidity & \multicolumn{3}{|c|}{$\begin{array}{c}\text { Desorption with Melon T=298 } \\
\text { (Without Treatment) }\end{array}$} & \multicolumn{3}{|c|}{$\begin{array}{c}\text { Desorption with Melon T=323 } \\
\text { (without treatment) }\end{array}$} \\
\hline $\boldsymbol{\varphi}$ & $\begin{array}{c}\text { U,Mol/ } \\
\mathrm{kg}\end{array}$ & $\begin{array}{c}\mathrm{V} \cdot 10^{-3} \\
\mathrm{~m}^{3} / \mathrm{kg}\end{array}$ & $\mathrm{L}, \mathrm{J} / \mathrm{mole}$ & $\mathrm{D} \cdot 10^{-9}, \mathrm{~m}$ & U,Mol/kg & $\begin{array}{c}\mathrm{V} 10^{-3} \\
\mathrm{~m}^{3} / \mathrm{kg}\end{array}$ & $\mathrm{LJ} / \mathrm{mole}$ & $\begin{array}{c}\mathrm{D} 10^{-9} \\
\mathrm{~m}\end{array}$ \\
\hline 0,8 & 19,4 & 0,34 & 552 & 10,2 & 13,87 & 0,24 & 598,8 & 6,87 \\
\hline 0,7 & 14,82 & 0,26 & 884 & 4,88 & 9,43 & 0,16 & 958,7 & 2,92 \\
\hline 0,6 & 12,54 & 0,22 & 1268 & 2,88 & 6,6 & 0,11 & 1374 & 1,43 \\
\hline 0,5 & 10,04 & 0,18 & 1717 & 1,7 & 4,44 & 0,07 & 1861 & 0,7 \\
\hline 0,4 & 8,7 & 0,156 & 2269 & 1,11 & 3,3 & 0,05 & 2455 & 0,4 \\
\hline 0,3 & 6,6 & 0,11 & 2983 & 0,64 & 2,7 & 0,04 & 3233 & 0,25 \\
\hline 0,2 & 5,6 & 0,10 & 3989 & 0,4 & 2,1 & 0,037 & 4323 & 0,14 \\
\hline
\end{tabular}

Table 2: Calculated data melon desorption.

\begin{tabular}{|c|c|c|c|c|c|c|c|c|}
\hline \multirow{2}{*}{$\begin{array}{c}\begin{array}{c}\text { Humidity } \\
\text { in } \\
\text { Chamber }\end{array} \\
\varphi\end{array}$} & \multicolumn{4}{|c|}{$\begin{array}{l}\text { Desorption Melon Stood } \\
\text { in syrup at } T=298 \mathrm{~K}\end{array}$} & \multicolumn{4}{|c|}{$\begin{array}{l}\text { Desorption Melon Stood } \\
\text { in syrup at } T=323\end{array}$} \\
\hline & $\begin{array}{c}\text { U,Mol I } \\
\text { kg }\end{array}$ & $\begin{array}{l}\mathrm{V} \cdot 10^{-3} \\
\mathrm{~m}^{3} / \mathbf{k g}\end{array}$ & L,J/mole & $\begin{array}{c}D \cdot 10^{-9} \\
\mathrm{~m}\end{array}$ & $\begin{array}{c}\text { U,Mol/ } \\
\text { kg }\end{array}$ & $\begin{array}{l}\mathrm{V} \cdot 10^{-3} \\
\mathrm{~m}^{3} / \mathrm{kg}\end{array}$ & L,J/mole & $D \cdot 10^{-}, \mathrm{m}$ \\
\hline 0,8 & 21,35 & 0,38 & 552 & 11,5 & 15,81 & 0,28 & 598,8 & 7,68 \\
\hline 0,7 & 17,8 & 0,32 & 884 & 5,97 & 12,21 & 0,21 & 958,7 & 3,71 \\
\hline 0,6 & 13,87 & 0,24 & 1268 & 3,25 & 8,65 & 0,15 & 1374 & 1,83 \\
\hline 0,5 & 12,43 & 0,223 & 1717 & 2,14 & 6,71 & 0,12 & 1861 & 1,05 \\
\hline 0,4 & 10,04 & 0,18 & 2269 & 1,31 & 4,4 & 0,07 & 2455 & 0,52 \\
\hline 0,3 & 6,93 & 0,12 & 2983 & 0,69 & 3,77 & 0,067 & 3233 & 0,33 \\
\hline 0,2 & 6,5 & 0,117 & 3989 & 0,43 & 2,8 & 0,05 & 4323 & 0,16 \\
\hline
\end{tabular}

Then, after the drying process is the measurement of water activity in the two products using laboratory equipment of "rotronic Hygro Palm" with an accuracy of $0.5-100 \%$ and the temperature in the range from 0.5 to $50^{\circ} \mathrm{C}$

Since we know the parameters of water activity in both products and the pore diameter of one of the varieties of melons we turn to the formula for determining the activity of water depending on the structure of the product.

$$
\begin{aligned}
& \alpha_{\omega}=e^{\frac{-2 \gamma \cos \theta v_{m}}{r R T}} \\
& \text { Or } \\
& r=\frac{-2 \gamma \cos \theta \cdot v_{m}}{R \cdot T \cdot \mathrm{h} a_{w}}
\end{aligned}
$$

$y$ - the surface tension of liquid; $0 /$ - contact angle of liquid with the wall of the capillary; R- gas constant; $r$ - radius of the capillary; $v$ - molar volume of liquid

Assume that during the processing of sugar syrup melon pulp adsorption of one and the other varieties formed a superficial solution to Gibbs identical in composition, we can assume that the surface tension and contact angle in the products are the same. Hence the average pore radius of another kind.

$$
r=\frac{r_{\text {melon }} \cdot a_{a b r i \mathrm{cot}}}{\grave{a}_{\text {melon }}}
$$

In these calculations do not take into account the correction factor which depends on: the real values of surface tension, contact angle of liquid with the wall, the chemical potential in the product Table 3.

\section{Conclusion}

The method of comparative analyses gives the opportunity to determine diameters of pores activity of water and other parameters in dried products. Investigated the hygroscopic properties of the pulp after melon combined drying method in a wide range of moisture and temperature environment, their structural characteristics, the quantity of energy due to moisture.

\section{References}

1. Dakworta RB (1980) Water in food products. Food industry.Moscow.

2. Kisilyov AV, Dreving VP (1973) Experimental methods in adsorption and molecular chromatography, Moscow University.

3. Giznburg AS, Gromov MA, Krasovskaya GI (1990) Thermo-physical properties of food products. Food industry. Handbook. (3rdedn) Moscow.

4. Giznburg AS, Safarov OF, Bazarbaeva DS (1983) Balanced moisture and effective diameter of grape pores. Conservation and vegetable drying industry 12: $16-18$.

5. Giznburg AS, Savina IM (1982) Massive moisture exchanging properties of food products. Light and food industry, Moscow.

6. Radjanov MF, Safarov OF (2009) Investigation of the process of osmotic drying of a melon. Chemistry and chemical technology 2: 72-74. 